\title{
Retraction
}

\section{Retracted: NKT Cells in Sepsis}

\section{Clinical and Developmental Immunology}

Received 12 November 2012; Accepted 12 November 2012

Copyright (C 2012 Clinical and Developmental Immunology. This is an open access article distributed under the Creative Commons Attribution License, which permits unrestricted use, distribution, and reproduction in any medium, provided the original work is properly cited.

This article has been retracted as it is essentially identical in content with the published article "NKT Cells: The Culprits of Sepsis?," Briana Leung and Hobart W. Harris, Journal of Surgical Research, Volume 167, Issue 1, Pages 87-95, 1 May 2011 [1].

\section{References}

[1] B. Leung and H. W. Harris, "NKT cells in sepsis," Clinical and Developmental Immunology, vol. 2010, Article ID 414650, 10 pages, 2010. 